\title{
AC 2007-183: NOT IN OUR BACKYARD: COMPUTER WASTE AND ENGINEERING ETHICS
}

\section{Marilyn Dyrud, Oregon Institute of Technology}

Marilyn Dyrud is a full professor in the Communication Department at Oregon Institute of Technology and regularly teaches courses in business and technical writing, rhetoric, public speaking, and ethics. She has been active in ASEE for over 20 years, serving as OIT's campus rep, ETD section rep, compiler of the annual engineering technology education bibligraphy, and is immediate past chair of the Pacific Northwest Section. In addition to ASSEE, she is active in the Association for Business Communication, where she chairs the Teaching Committee, edits a pedagogical column for one of the association's journals, and sits on the editorial boards for two journals, and the Association for Practical and Professional Ethics. 


\section{Not in Our Backyard: Computer Waste and Engineering Ethics}

\section{Introduction}

The electronic gadgetry boom spawned by the development of personal computers in the 1970s has a decidedly dark side emerging in the 21 st century: electronic waste, or e-waste, is accumulating by the millions of tons due to ineffectual recycling programs and lack of an enforced international policy governing the disposal of outmoded or unwanted electronic devices. It is, according to The Wall Street Journal, "the world's fastest growing and potentially most dangerous waste problem."1

E-waste consists of discarded electronics, primarily smaller consumer products: cell phones, digital cameras, GPS units, fax machines, MP3 players, gaming consoles and players, television sets, DVD/VHS players, stereos, PDAs, PCs and peripherals. This paper, however, focuses only on computer waste, explaining potential health hazards, the scope of the problem, international legislation, ethical issues involved, and classroom activities.

The problem is huge and growing. In the US, for example, individuals, businesses, and governmental/non-governmental agencies discard about 136,000 PCs daily- ${ }^{2}$ more than 10,000 a week from the federal government alone- ${ }^{3}$ totaling some 250 million units annually. ${ }^{1}$ While some are technologically obsolete, most are not. They are, however, psychologically obsolete, as the life of a PC has deceased from five years in 1997 to two currently. ${ }^{4}$ About $70 \%$ of old PCs languish in basements and attics, collecting dust ${ }^{5}$ some 60 million lie in municipal landfills. ${ }^{1}$ Less than $10 \%$ are recycled, ${ }^{6}$ and, of those, most are destined for disassembly in third world countries. In fact, about $80 \%$ of "recycling" efforts in the US consist of exporting e-waste abroad. ${ }^{7}$ Exporting old PCs has resulted in environmental degradation and public health risks in the recipient countries.

\section{Health Hazards}

A computer sitting on a desk poses no health risk. However, a computer hacked apart via hammer and chisel exposes toxic elements that result in human and environmental damage. Computers are considered hazardous waste because they contain 34 distinct toxic substances, ${ }^{8}$ some, like antimony and beryllium, in small quantities, and others, like lead and plastics, in abundance. The following discusses the major toxins, and Table 1 summarizes the effects and total estimated weight of toxins in the 315 million computers deemed obsolete between 1997 and 2004.

\section{Lead}

Lead is the second most abundant element in computers, with the average monitor containing 3-8 pounds. It is mostly concentrated in the CRT glass panel, but the solder in circuit boards is also lead-based. Discarded electronics account for about $40 \%$ of lead in US landfills. ${ }^{3}$ 
The toxicity of lead has been known for decades and resulted in the 1970s ban on leaded gasoline and paint in the US. Once in the body, lead damages systems vital for development: nervous, blood, reproductive, and endocrine. In fetuses and small children, lead ingestion or exposure can affect brain development. In the environment, lead neither biodegrades nor dissolves. ${ }^{9}$

\section{Cadmium}

Cadmium is used as a plastics stabilizer and can also be found in older CRTs. In newer computers, it is used in SMD chip resistors, semiconductors, rechargeable batteries, and infrared detectors. ${ }^{10}$ Repeated exposure to cadmium can lead to liver, lung, and bone damage, as well as renal failure. ${ }^{11,12}$ While cadmium occurs naturally in the environment, it has a half-life of 30 years and can accumulate to poisonous levels through leakage, which occurs in third world computer "recycling" centers. ${ }^{11}$

\section{Mercury}

Found in flat panel light displays, switches, and printed wiring boards, mercury can cross over the placenta and harm developing fetuses, as well as pass through breast milk. ${ }^{10}$ Methylated mercury, which forms as a result of organic mercury settling in bottom sediments, can cause brain and kidney damage. ${ }^{13}$

Like cadmium, mercury occurs naturally in the environment. ${ }^{14}$ However, discarded electronics can release high levels into the environment, which then move up the food chain. About $22 \%$ of the world's annual consumption of mercury is for electronics. ${ }^{11}$

\section{Hexavalent chromium}

Damage resulting from hexavalent chromium, or chromium VI, was brought to public attention in the 2000 film Erin Brockovich, which details water pollution in the tiny desert town of Hinkley, California. Computer manufacturers use chromium VI to prevent corrosion to untreated and galvanized plates and to harden or decorate the steel housing. ${ }^{10}$ Released into the environment, chromium VI may cause asthmatic bronchitis and DNA damage. When inhaled, high levels are carcinogenic. ${ }^{15}$

\section{Plastics}

Plastics, in various forms, are the most prevalent substances in PCs, averaging about 13.8 pounds per unit. ${ }^{11}$ Plastics are used in the CPU case, CRT housing, keyboard, as well as printed circuit boards, connectors, and cable covers. Often, plastics are combined, which makes recycling nearly impossible, as separating the different compounds is time-consuming and expensive. ${ }^{10}$

PVC, in particular, poses a human health hazard: when burned, it releases dioxins, which have a devastating effect on humans, settling in body fat. ${ }^{11}$ According to studies conducted by the National Institute of Environmental Health Sciences, dioxin exposure can result in "reproductive 
and developmental problems, increased heart disease and increased diabetes," as well as possible birth defects. ${ }^{16}$

\section{Brominated flame retardants}

These varied substances-about 75 different chemicals are classified as brominated flame retardants (BFRs) ${ }^{16}$-are used in computers and other electronic devices to reduce flammability, but they are present in other consumer goods as well, including TV sets and kitchen appliances. ${ }^{11}$ Printed circuit boards, connectors, covers, and cables all contain BFRs. Although data are slim, research indicates that BFR effects on humans include digestive cancers and a reduction in the production of thyroxin, a thyroid hormone that regulates development. ${ }^{11,17}$

Table 1. Health risks associated with common computer substances ${ }^{10,11,13}$

\begin{tabular}{|l|l|l|}
\hline \multicolumn{1}{|c|}{ Substance } & \multicolumn{1}{|c|}{ Possible health effects/damage } & \multicolumn{1}{c|}{$\begin{array}{c}\mathbf{1 9 9 7 - 2 0 0 4} \text { total weight } \\
\text { (in pounds) }\end{array}$} \\
\hline Lead & $\begin{array}{l}\text { Nervous, blood, endocrine, reproductive } \\
\text { systems, kidneys, brain development }\end{array}$ & 1.2 billion \\
\hline Cadmium & Kidneys & 2.0 million \\
\hline Mercury* & Brain and kidneys; fetal damage & 400,000 \\
\hline Chromium VI & $\begin{array}{l}\text { Lung and DNA damage; asthmatic } \\
\text { bronchitis; cancer }\end{array}$ & 1.2 million \\
\hline PVC & Cancer, DNA damage & 1.5 billion \\
\hline $\begin{array}{l}\text { Brominated flame } \\
\text { retardants }\end{array}$ & $\begin{array}{l}\text { Cancer: stomach, pancreas, liver, and } \\
\text { lymph }\end{array}$ & 350 million \\
* Methylated &
\end{tabular}

\section{Other}

In addition to these substances, computers also contain phosphor, mainly found in screen coatings on older CRTs and declared "extremely toxic" by the Navy, and beryllium, used on motherboards and connectors, and linked to lung cancer. ${ }^{10}$ Barium, used on CRTs for protection from radiation, can cause brain swelling, weakness in muscles, and spleen, liver, and heart damage. ${ }^{18}$ An assortment of heavy metals and other potentially harmful elements, such as arsenic, complete the toxic cocktail. ${ }^{11}$

\section{Scope}

The amount of e-waste accumulating in both industrialized and developing nations is enormous and growing at an alarming rate. Predictions indicate that 716 million new PCs will be used worldwide by $2010,{ }^{19}$ including 178 million and 80 million new users in China and India, respectively. ${ }^{20}$ Currently, e-waste accounts for about $5 \%$ of the municipal solid waste stream, ${ }^{13}$ but, according to Greenpeace International, it is increasing nearly three times faster than the total; 
e-waste production in developing nations is anticipated to triple in the next five years. ${ }^{20}$

In 1989, some 160 countries signed the Basel Convention on the Transboundary Movements of Hazardous Wastes and Their Disposal, which took effect in $1992^{21,22}$ and was further amended in $1995 .^{13}$ The treaty essentially prohibits exportation of hazardous wastes from wealthy nations to poorer ones. The US elected not to sign, the only industrialized nation in the world to do so. The irony is painful, since the US is the world's largest producer, and hence exporter, of computer trash, sending millions of tons annually to cities in Asia and Africa; other major exporters include Europe and Japan. The results have been devastating. The following three cases are representative of the consequences of rich countries using poorer nations as e-waste dumpsites.

\section{Guiyu, China}

Four hours northwest of Hong Kong, lies Guiyu, an area consisting of several small villages nestled along the Lianjiang River. Prior to 1995, Guiyu's major product was rice. After 1995, the major activity was computer recycling, focusing on materials recovery, which has transformed the once pastoral community into a toxic dump: mountains of computer debris clog the streets, and the river frequently changes color, depending which plastic residue is dumped into it.

In 2001, the region was visited by an environmental contingent representing the Basel Action Network (BAN), a Seattle-based wing of Greenpeace International, and the Silicon Valley Toxics Coalition (SVTC), a California-based group dedicated to promoting "human health and environmental justice in response to the rapid growth of the high-tech industry." 23 In conjunction with three local groups in China, India, and Pakistan, they produced Exporting Harm: The HighTech Trashing of Asia, a seminal report which exposes the environmental damage and human suffering caused by "recycling" centers such as Guiyu. It is, as BAN director Jim Puckett explains, "a cyber-age nightmare."13 This is despite a 2000 Chinese government ban on importing monitors and computers. ${ }^{19}$

Guiyu is "a computer slaughterhouse," processing about 1.5 millions tons of e-waste annually, which yields about $\$ 75$ million. ${ }^{24}$ "Recycling" work in the Guiyu region is divided into sectors, depending on the computer component undergoing disassembly, and over 100,000 workers are involved, using low tech tools-hammers, pliers, etc.-or their bare hands to disassemble the units, thus releasing harmful compounds into the air, water, and soil. In one sector, workers use hammers to smash CRTs and access the copper yoke. In another, workers wash circuit boards in acid baths to extract the trace amounts of gold and silver in chips. In yet another, workers strip wires for copper. On the sidewalks of another sector, workers use coal braziers to melt plastic on motherboards. All unmarketable debris is burned, and the residue deposited in the river, as is acid from the baths. ${ }^{13}$

Workers are paid $\$ 1.50$ a day, nearly double the typical salary, and are afforded no bodily protection, such as goggles, masks, or gloves. ${ }^{25}$ While no longitudinal health data yet exist, reports from Shantou University's Medical Health Colleges indicate that $88 \%$ of Guiyu's 
workers have developed skin diseases or "neurological, respiratory or digestive disorders," 26 and area schoolteachers report breathing problems in $50 \%$ of their students. ${ }^{5}$ Guiyu is, however, a magnet for workers due to high demand and high salaries. As worker Li Xui Lan, interviewed as she was disemboweling a PC, explained, "Back home, there are no jobs. There is no money. There is nothing to do."26

While e-waste scavenging provides jobs, it has had a shocking effect on the environment: according to testing conducted in Guangdong Province, the site of Guiyu and other recycling centers, heavy pollution exists in $20 \%$ of rivers and $55 \%$ of precipitation is acid rain. ${ }^{27}$ Drinking water is so contaminated that it has to be trucked in: lead levels are 2,400 times higher than World Health Organization guidelines. Spot soil samples revealed astonishingly high levels of barium (10 times higher than the EPA threshold), tin (152 times higher), and chromium (1,338 times higher). Copper so saturated the soil that it accounted for $13.6 \%$ of the total sample. ${ }^{13} \mathrm{~A}$ 2005 Greenpeace report concludes that the result of the electronic recycling business in China and India is "severe contamination of the workplace and adjacent environment with a range of toxic metals and persistent organic contaminants." 28

In 2004, the Chinese government passed a certification system for countries exporting e-waste to China. ${ }^{29}$ Although much still enters the country illegally, ${ }^{30}$ part of the waste stream is being diverted to Vietnam, Indonesia, and the Philippines. ${ }^{29}$

\section{Manila, Philippines}

Manila, long famous for "Smoky Mountain," a towering 40-year-old garbage dump that serves as home to an estimated 30,000 people, ${ }^{31}$ is also becoming a dumpsite for e-waste. ${ }^{32}$ While the problem is not nearly so acute as in Guiyu, the country's burgeoning electronics industry and annual import of over 400,000 used PCs do not bode well for the future. ${ }^{33}$

Although the Philippines ratified the Basel Convention and has its own internal legislation regulating the importation of hazardous waste, e-waste slips in under the guise of recycling, catering to a huge second-hand market for refurbished electronics. ${ }^{34}$ However, only about $10 \%$ of imported units are refurbishable, and the other $90 \%$ is contracted out to IRI and HMR, the Philippines' primary recycling businesses. While they use machinery, rather than human beings, to crush units and extract recyclables, these facilities are unregulated, ${ }^{33}$ and much e-waste ends up in backyard scavenging operations that resemble those of Guiyu.

Residue is carted to landfills, where it is picked over by the denizens of garbage heaps. Like the Guiyu workers, the dumpsite wastepickers use low tech methods and no physical protection to extract resalable elements, including acid baths for gold extraction. And, as in China, unusable materials end up contaminating workers, air, soil, and water. ${ }^{34}$ A USAID report notes that of the country's 400 rivers, 50\% "are characterized as biologically dead due to contamination from industrial and residential run-off...[and] the lack of a central hazardous waste treatment facility is a major obstacle in properly disposing of toxic and hazardous waste." 29 
In 1987, Nigeria became the site of one of the first cases of global toxic waste dumping, courtesy of an Italian businessman who contracted with a Nigerian landowner to store 18,000 barrels of "construction materials," containing PCBs, asbestos, and dioxins, at the tiny port of Koko Beach. The scandal that ensued after the barrels started leaking was a catalyst for the 1989 Basel Convention. ${ }^{35}$

In more recent years, Lagos, the second largest city in the world, has been the recipient of nearly 400,000 used computers a month. ${ }^{36}$ While the situation in Nigeria is very different from that of Guiyu, the results are similar: environmental degradation and the potential for serious health risks.

Unlike China, where the emphasis is on materials recovery, Nigeria focuses on repair and refurbishment of outdated computers. Hence, the streets of Lagos are not clogged with mountains of computer components awaiting disembowelment; rather, the city has enormous warehouses piled high with thousands and thousands of old computers and peripherals awaiting rejuvenation. The US and Europe each account for about $45 \%$ of imports, with the final $10 \%$ coming from other countries, including Israel and Japan. ${ }^{35}$

Handled properly, computer repair could be a growth business. ${ }^{37}$ However, about $75 \%$ of computer units sent to Lagos for repair and refurbishment are useless junk, and the city has no operations for materials recovery, outside of a few shops that crack open CRTs for the copper yokes. ${ }^{35}$

While cottage industries operating out of several large marketplaces manage to repair and resell some of the units, most are taken to local unlined landfills, which regularly leak. The leachate is not recovered and quickly reaches ground water, only 3-6' below the surface. To reduce the amount of waste in the landfills, they are regularly set on fire, releasing dioxins and heavy metals into the atmosphere. Even more disconcerting is the fact that any unused piece of land can be used as a dumpsite, and scavengers regularly pick through the debris for minute pieces of valuable metals, thus exposing themselves-and their children playing in the heaps-to carcinogens. ${ }^{35}$

By classifying e-waste sent to Nigeria as "reusable," exporting countries are doing an end-run around Basel Convention provisions. Rather than sending reparable electronics, these countries are simply off-loading hazardous wastes.

\section{Legislation}

The alarming data released in reports from international environmental agencies should spawn a flurry of worldwide legislative activity aimed at curtailing and controlling the problem. The 1989 Basel Convention and subsequent amendment certainly were steps in the right direction, although enforcement is a debatable issue. The following describes recent legislation directed at curbing the e-waste flow and developing more responsible manufacturing processes. 


\section{European Union}

Member states of the European Union have passed and are implementing two pieces of legislation that will have international repercussions: the Waste of Electrical and Electronic Equipment Directive (WEEE) and the Restriction on Hazardous Substances Directive (RoHS).

Producer responsibility is the basis for WEEE; it requires all producers of equipment designated in the directive to set up, at their own expense, centers for collecting, treating, recovering, and disposing of wastes or buy into a collective for those purposes. The 10 product categories specified by WEEE include household appliances, consumer and sports equipment, IT devices, vending machines, lighting and monitoring equipment, medical devices, and tools. WEEE provisions apply not only to the EU but to products from all countries exporting goods to member states. ${ }^{38}$

RoHS aims at curtailing, and eventually eliminating, known hazardous substances in electronic devices. As of July 2006, member states cannot market products that contain the following:

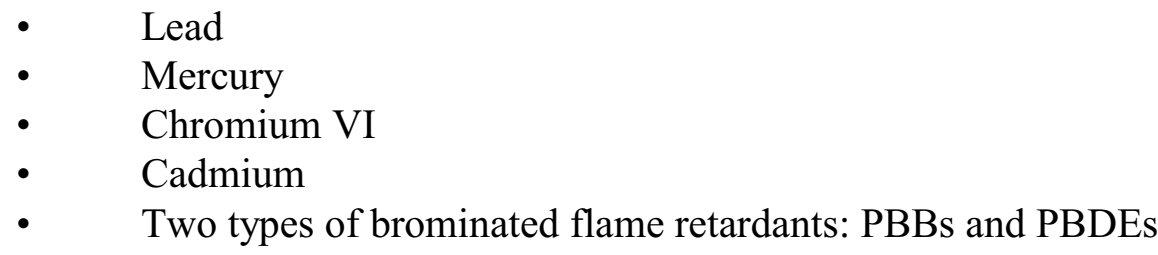

Certain exemptions exist, such as lead in CRTs, but these are subject to a four-year review cycle. ${ }^{38}$ Like WEEE, the RoHS Directive applies to imports from abroad as well as EUmanufactured products.

If properly enforced, these two directives will have a dramatic impact internationally on the design, manufacture, and disposal of those products that now account for the bulk of e-waste. "Indeed," suggests Max Robinson, writing for the Air Conditioning, Heating, Refrigeration News, " the continued business success of many manufacturing concerns will be influenced not just by compliance, but by proactive work in meeting the requirements." 39

\section{Japan}

Japan was one of the first countries to pass legislation based on the principle of producer responsibility. ${ }^{40}$ Starting in 1991, Japan enacted a series of recycling laws designed to both promote awareness of recycling and require businesses to take back and recycle old products such as washing machines and TVs when consumers purchase a newer model. Consumers pay a recycling fee, ranging from $\$ 21-41 \mathrm{US}^{38}$

In 2001, recycling laws extended to electronics for businesses and in 2003 to consumer electronics. Disposing of computers manufactured prior to 2003 requires consumers to pay an "end of life" fee. Newer computers have a fee built into the retail price. ${ }^{38}$ 
As of July 2006, exporters of designated products to the Japanese market must meet similar hazardous substance restrictions as those imposed by RoHS. Dubbed J-MOSS, the law does not ban those substances, but they require labeling and reporting. ${ }^{41}$

\section{United States}

While other nations are making impressive strides in passing legislation with an eye to the future and the safety of the planet's population, the US seems to be suffering from environmental myopia. The world's largest producer and exporter of electronic waste has no national policy governing exportation and disposal of e-waste, and state legislation is a patchwork quilt, if it exists at all. In fact, only a handful of states have passed laws related to e-waste, and these deal primarily with the disposal issue. ${ }^{42}$ California's is the most progressive, as it emulates the EU's WEEE, and prohibits consumers from throwing out even batteries and fluorescent light bulbs. ${ }^{43}$

The reasons why the US has no significant e-waste legislation are complex and somewhat dependant upon the capitalist economic system, which requires that consumers spend in order to keep the economy running. Thus products, while probably not technically obsolete, have a builtin psychological obsolescence factor to keep consumers spending. The computer industry typifies this concept: a computer with a 486 chip is still perfectly usable for many different applications, but consumers apparently want-encouraged by insistent advertising-more current technology. There is, suggests Alastair Iles, a certain "cultural reluctance" to upgrade or recycle.

Alan Hifa, Maimonides Medical Center's chief psychologist, offers a provocative theory: in the US, our interaction with technology, and hence our psychological investment, has waned considerably: "We are so bombarded with technology and electronics now, it has somewhat lost its luster." ${ }^{44}$ With less emotional attachment to our gadgets, it is easier simply to toss them out.

Another reason involves a recycling fee charged for acceptance of old electronics. Were it included in the retail price, most consumers would not even notice. However, as Chad Raphael of the Markkula Center for Applied Ethics points out, voluntary recycling programs that involve even a small fee are ineffectual. ${ }^{45}$ And while federal legislation has been proposed, the bills tend to languish in Congress. ${ }^{42}$

\section{Ethical Issues}

If ethics has one prime directive, it is "do no harm." As a foundational concept, it should govern human actions-from interpersonal relationships to manufacturing processes-emphasizing justice and responsibility. All three of these concepts, when applied to the growing problem of e-waste, are useful in impressing upon students the urgency for solutions. If as students they can understand the ethical dimensions of the problem, then perhaps as professionals they can actively contribute to solutions.

Classroom discussions about e-waste can be challenging, as students tend to have fairly narrow definitions of justice and responsibility coupled with provincial outlooks. As a recent crop of papers illustrate, my students tend of view justice as equity and responsibility as accountability; they are also confused by Peter French's concept of corporations as moral agents. ${ }^{46}$ However, e- 
waste is an international issue that must be so addressed. Therefore, it is helpful to have students rethink their perspectives and their definitions. Alastair Iles' insightful "Mapping Environmental Justice in Technology Flows," offers a different view of justice: "Justice is not simply a matter of seeking fairer distribution, but of demanding changes in the very character of production and development." Justice "obviates the risks of everyone...." Such a definition broadens the concept as well as underscores the need for activism, both professional and personal.

The same is true of responsibility; it involves much more than holding a manufacturer responsible for its products, a view which tends to emphasize end-of-life issues, rather than conceptual ones. To initiate solutions, the international engineering community must first examine design: why do electronic products include such potentially damaging materials? Building in the currently popular gambit, "extended producer responsibility," which holds manufacturers responsible for the fate of products that are no longer useful, ${ }^{47}$ accentuates end-oflife. The "ecological footprint" approach, however, looks at a shared consumer-producer responsibility. ${ }^{48}$ The electronics industry has an enormous ecological footprint, requiring, according to 2003 United Nations University data, the following resources for the production of a single PC: 240 kilos of fossil fuels, 22 kilos of chemicals, 1.5 tons of water. ${ }^{5}$ Surely such inordinate consumption cannot continue indefinitely, and our future engineers may someday hold positions with the power to effect positive change.

\section{Classroom Activities}

With a projected half a billion obsolete computers in the US alone by the end of $2007,{ }^{24}$ the issues regarding computer trash are fertile ground for exploration in all engineering curricula, since the technology is an essential tool of the profession. In addition to providing readings and leading discussions, which is my current approach, instructors can develop a number of research projects that may yield enlightening results, such as the following examples:

- Have students investigate how their own universities deal with outmoded computers and peripherals. The results may be both frustrating, due to a lack of cooperation or intentionally vague information, and surprising: universities may dump unusable/unmarketable PCs in landfills (University of North Dakota), send them to state prisons for recycling (Texas A \& M, College Station), pay materials recovery firms to take them (University of Minnesota, Twin Cities), or pay recyclers to cart them away and hope they are not exported (New York University). ${ }^{49}$

- Have students research corporate "takeback" programs, such as those at Sony (rated \#1 by Greenpeace International) and Toshiba (rated dead last). ${ }^{50}$ What are attributes of the most and least effective programs? How can corporations both improve their images and become more environmentally responsive?

- Ask students to examine their states' laws regarding e-waste recycling and disposal. Bills tend to fall into one of these categories: takeback, advanced recycling fees, study, and 
disposal bans. ${ }^{51}$ In my own state of Oregon, formerly a leader in progressive recycling legislation, a major electronic stewardship bill has been languishing in committee for two years. ${ }^{52}$

- Have students research e-waste in relationship to sustainability, as defined by their particular professional organization. Has the ASME, for example, responded to the challenges of dealing with obsolete technology? How? What further measures can the organization take to alleviate the problem? How can members contribute?

To make an emotional impact on students, consider showing the Exporting Harm video in class. Students will gain a visual picture of the effects of e-waste dumping in China. It is difficult to watch this film without feeling compassion for those so grievously affected.

\section{Conclusion}

"Too often," suggests BAN director Jim Puckett, "justifications of 'building bridges over the digital divide' are used as excuses to obscure and ignore the fact that these bridges double as toxic waste pipelines to some of the poorest communities and countries in the world. While supposedly closing the 'digital divide,' we are opening a 'digital dump'...[creating] an electronic tsunami" ${ }^{35}$ crashing over the third world.

The images of workers hip deep in exposed circuitry, inhaling noxious fumes with every breath; of children romping in ash heaps and tottering over hillocks of crushed monitors; of cattle serenely grazing on poisoned land; of women washing clothes and cooking with water so contaminated that it devours metal: all tug at the heartstrings and silently cry for a justice that is not forthcoming from an international community that could easily mitigate the deplorable conditions caused by thrusting the computer revolution's waste on the poorest of the poor.

Computers have become the primary tool of engineers, but most of our students surely do not understand what can happen to that tool when it is no longer useful. Engineering educators must expose students to the consequences of exporting obsolete technology, to raise awareness and help alleviate some of the physical suffering and environmental degradation caused by this particular form of third world product dumping.

\section{References}

1. Grossman, Elizabeth. "Mountain of High-Tech Trash Presents a World of Problems." Seattle PostIntelligencer (August 20, 2006): D1.

2. Royte, Elizabeth. “E-Gad!” Smithsonian 36, no. 5 (August 2005): 82-6.

3. Eilperin, Juliet. "Dead Electronics Going to Waste; Millions of Tons of Used Devices Pose Threat to Environment." The Washington Post (January 21, 2005): A04. 
4. Fact Sheet-Electronic Waste (E-Waste): The Hidden Harm of the Technological Revolution. (n.d.). Retrieved from http://environment.about.com/cs/ewaste/a/ewaste.htm.

5. Iles, Alastair. "Mapping Environmental Justice in Technology Flows: Computer Waste Impacts in Asia." Global Environmental Politics 4, no. 4 (November 2004): 76-107.

6. "Who's Recycling Techno Trash?" Wired News (December 5, 2006). Retrieved from http://wiredvig.wired.com/news/print/0,1294,65932,00.htm.

7. "Is America Exporting a Huge Environmental Problem? Old Computers Often End Up in Toxic Heaps in Developing Countries." $A B C$ News (January 6, 2006). Retrieved from http://abcnews.go.com/2020/ Technology/story?id=1479506.

8. Batto, Amos. A Better Upgrade, Not a Faster Throw-Away: An Activist Guide to Minimizing the Social and Environmental Impact of Computers and Reforming the Industry (September 2006). Retrieved from http://www.ciber-runa.net/guide/BetterUpgrade-ActivistsGuide.pdf.

9. “Lead Poisoning Dangers.” Lead Poisoning News.com (n.d.). Retrieved from http://www.lead-poisoningnews.com $/ \mathrm{html} /$ dangers.html.

10. Clean Computer Campaign. (n.d.). Retrieved from http://www.computertakeback.com/docUploads/ compoutertoxics\%2Epdf?CFID=4790365\&CFTOREN=26464748.

11. Silicon Valley Toxics Coalition. Just Say No to E-Waste: Background Document on Hazards and Waste from Computers (1999). Retrieved from http://svtc.igc.org/pubs/sayno.htm.

12. Agency for Toxic Substances and Disease Registry. Public Health Statement on Cadmium (July 1999). Retrieved from http://www.atsdr.cdc.gov/toxprofiles/phs5.html.

13 Puckett, Jim et al. Exporting Harm: The High-Tech Trashing of Asia. Basel Action Network (February 25, 2002). Retrieved from http://www.crra.com/ewaste/ttrash $2 / \operatorname{trash} 2 /$.

14. Center for Policy Alternatives. Mercury Poisoning Prevention (2006). Retrieved from http://www.stateaction. org/issues/issue.cfm/issue/MercuryPoisoning.xml.

15. Environmental Protection Agency. Chromium Compounds Hazard Summary (January 2000). Retrieved from http://www.epa.gov/ttn/atw/hlthef/chromium.html.

16. National Institute of Environmental Health Sciences. Dioxin Research (April 24, 2001). Retrieved from http://www.niehs.nih.gov/oc/factsheets/dioxin.htm.

17. Birnbaum, Linda S., and Daniele F. Staskal. "Brominated Flame Retardants: Cause for Concern?" Environmental Health Perspectives 112, no.1 ( January 2004): 9-17.

18. Rayner, Mary, and Bruce Bingham. "Do You Compute?” Ethical Consumer 84 (August/September 2003). Retrieved from http://www.ethiscore.org/info.aspx?info=reports/full/computers

19. De Guzman, Mari-Len. "The Pungent Stench of E-Waste." ComputerWorld Canada 21, no. 17 (August 19 , 2005). Retrieved from Lexis-Nexis database.

20. Greenpeace International. The E-Waste Problem (n.d.). Retrieved from http://www.greenpeace.org/ international /campaigns/toxics/electronics/the-e-waste-problem.

21. Bosire, Bogono. "UN Seeks to Save Developing World from E-Waste." Agence France Press-English (November 26, 2006). Retrieved from Lexis-Nexis database. 
22. Selva, Meera. “Toxic Shock.” The Independent (September 21, 2006): 24.

23. Silicon Valley Toxics Coalition. About Us ( n.d.). Retrieved from http://svtc.etoxics.org/site/PageServer? pagename $=$ svtc_about_us.

24. Johnson, Tim. "E-Waste Dump of the World.” Seattle-Times (April 9, 2006): A3.

25. “The World's Rubbish Dump.” South China Morning Post (September 17, 2006): 13.

26. "Much Toxic Computer Waste Lands in Third World." USA Today (February 25, 2002). Retrieved from http://usatoday.com/news/2002/02/25/computer-waste.htm.

27. Chea, Terrence. American Electronic Waste Contaminates China and India (August 17, 2005). Retrieved from http://www.minesand communities.org/Action/press708.htm.

28. Brigden, K. et al. Recycling of Electronic Wastes in India and China: Workplace and Environmental Contamination. Greenpeace International (August 2005). Retrieved from http://www.greenpeace.org/ $\mathrm{raw} /$ content/international/press/reports/recycling-of-electronic-waste.pdf.

29. Bortner, Robert. Asia Near East (ANE) Computer Recycling and Disposal (E-Waste): Preliminary Research Paper. USAID (n.d.). Retrieved from http://www.dot-alliance.org/resourceprtdb/uploads/ partnerfile/upload/258/Ewaste\%20Research\%20Final.doc.

30. Grossman, Elizabeth. Where Computers Go To Die-And Kill (April 10, 2006). Retrieved from http://www.salon.com/news/feature/2006/04/10/ewaste.html.

31. Escobar, Pepe. "Poverty, Corruption: The Ties That Bind." Asia Times (October 5, 2004). Retrieved from http://www.atimes.com/atimes/Southeast Asia/FJ05Ae01.html.

32. Robles, Alan. "Computer Graveyard." South China Morning Post (April 21, 2005): 13.

33. Greenpeace International. Toxic Tech: Looming E-Waste Problems for Thailand and Philippines (September 28, 2005). Retrieved from http://www.greenpeace.org/seasia/en/news/toxic_threat_in_th_rp.

34. Greenpeace International. Pulling the Plug on Dirty Electronics in Southeast Asia (September 2005). Retrieved from http://www.greenpeace.org/raw/content/seasia/en/press/reports/toxictech_in_sea.pdf.

35. Puckett, Jim et al. The Digital Dump: Exporting Re-use and Abuse to Africa. Greenpeace International (October 24, 2005). Retrieved from http://www.ban.org/BANreports/10-24-05/documents /TheDigitalDump.pdf.

36. Flynn, Laurie. "Poor Nations Are Littered with Old PC's, Report Says." The New York Times (October 24, 2005): C5

37. Coomson, Joseph. "The Digital Divide Becomes a Digital Dump." Ghanian Chronicle (February 8, 2006). Retrieved from Lexis-Nexis database.

38. Daly, Laureen et al. Recycling Technology Products. US Department of Commerce, Office of Technology Policy (July 2006). Retrieved from http://www.technology.gov/reports/2006/Recycling/Beg-Apendix7.pdf.

39. Robinson, Max. "The Impact of WEEE and RoHS on the U.S." Air Conditioning, Heating, Refrigeration News (May 15, 2006). Retrieved from http://www.achrnews.com/CDA/Articles/Technical/ b07579923af4b010VgnVCM100000f932a8c0 
40. Clean Production Action. Japan-Electronics (2007). Retrieved from http://www.cleanproduction.org/ Producer.International.Japan.Electronics.php.

41. Ministry of Economy, Trade and Industry. Obligation to Provide Information on Chemical Substances Contained in Home Appliances and PCs (July 1, 2006). Retrieved from http://www.meti.go.jp/ policy/recycle/main/3r_policy/policy/pdf/j-moss_english.pdf.

42. Grossman, Elizabeth. "Digital Dilemma." Waste Age (August 1, 2006). Retrieved from http://wasteage.com/mag/waste_digital_dilemma/.

43. Marshall, Matt. "Tossing E-Waste Is Not So Easy: Plethora of Recycling Programs, Laws Confusing." San Jose Mercury News (May 8, 2006). Retrieved from Lexis-Nexis database.

44. Hoo, Stephanie. Castoffs Filling National's Landfills.” Herald and News (January 24, 2007): D!.

45. Raphael, Chad. Taking Responsibility for E-Waste. Markkula Center for Applied Ethics (March 8, 2002). Retrieved from http:/www.scu.edu/ethics/publications/ethicalperspectives/rapheal.html.

46. French, Peter. "Corporate Moral Agency," in Ethical Issues in Professional Life, ed. Joan C. Callahan. New York: Oxford University Press, 1988.

47. Hanisch, Carola. "Is Extended Producer Responsibility Effective?" Environmental Science and Technology 34, no.7 (April 1, 2000): 170A-175A.

48. Lenzen, Manfred et al. Shared Producer and Consumer Responsibility - Theory and Practice (2006). Retrieved from http://www.isa.org.usyd.edu.au/publications/documents/Lenzen,Murray,Sack\&Wiedmann_2006Shared_Responsibility.pdf.

49. Carlson, Scott. “Old Computers Never Die-They Just Cost Colleges Money in New Ways." Chronicle of Higher Education (February 14, 2003): A33-35.

50. Greenpeace International. How the Companies Line Up (n.d.). Retrieved from http://www.greenpeace.org/ international/campaigns/toxics/electronics/how-the-companies-line-up.

51. Computer Takeback Campaign. E-Waste Bills by State (n.d.). Retrieved from http://www.computertakeback. com/docUploads/Ewaste_legislation_state_summary2006.xls.

52. Recycling Advocates. Advanced Recovery Fee (ARF): The Way to Go (April 2005). Retrieved from http://www.recyclingadvocates.org/newsletter/apr2005.htm\#arf. 